\title{
The complex genetics in autism spectrum disorders
}

\author{
HUA Rui ${ }^{\dagger}$, WEI MengPing ${ }^{\dagger} \&$ ZHANG Chen ${ }^{*}$ \\ State Key Laboratory of Membrane Biology, School of Life Sciences; PKU-IDG/McGovern Institute for Brain Research, Peking University, \\ Beijing 100871, China
}

\begin{abstract}
Autism spectrum disorders (ASD) are a pervasive neurodevelopmental disease characterized by deficits in social interaction and nonverbal communication, as well as restricted interests and stereotypical behavior. Genetic changes/heritability is one of the major contributing factors, and hundreds to thousands of causative and susceptible genes, copy number variants (CNVs), linkage regions, and microRNAs have been associated with ASD which clearly indicates that ASD is a complex genetic disorder. Here, we will briefly summarize some of the high-confidence genetic changes in ASD and their possible roles in their pathogenesis.
\end{abstract}

autism spectrum disorders, genetics, causative genes, copy number variants

Citation: $\quad$ Hua R, Wei MP, Zhang C. The complex genetics in autism spectrum disorders. Sci China Life Sci, 2015, 58: 933-945, doi: $10.1007 / \mathrm{s} 11427-015-4893-5$

Autism, first described by Leo Kanner in 1943, is a pervasive neurodevelopmental disorder that primarily affects children. In the Diagnostic and Statistical Manual of Mental Disorders, Fifth Edition (DSM-V), published in 2013, autism was merged into a broader category, called autism spectrum disorders (ASD), which also includes Asperger's syndrome, pervasive developmental disorders not otherwise specified (PDD NOS), and childhood disintegrative disorder (CDD; also known as Heller's syndrome). As a single diagnostic category, individuals with ASD show common deficits in social interaction and nonverbal communication, as well as restricted interests and stereotypical behavior. Although the exact cause of ASD remains unclear, genetic changes/heritability is one of the major contributing factors [1-3]. There are three lines of evidence to support this: (i) Early epidemiologic studies found that the chance of having a child with ASD is significantly higher in families that already have one child with ASD; in addition, the core

$\dagger$ Contributed equally to this work

*Corresponding author (email: ch.zhang@pku.edu.cn) autistic symptoms, such as social impairments and repetitive behavior, show aggregation in multiplex autistic families [4-6]. (ii) Multiple twin studies have also shown that the concordance rate for autism ranges from $36 \%$ to $95 \%$ in monozygotic twins, which is much higher than the rate observed in dizygotic twins and the general population. Similarly, the concordance for social and cognitive deficits follows the same rank, monozygotic $>$ dizygotic $>$ general population [7-12]. (iii) The male:female ratio of individuals with ASD is 4:1, indicating a preferred localization of causal genes on the X-chromosome. Thus, ASD is a heritable, neuropsychiatric disease.

Mounting efforts using different methods, from case studies to genome-wide association studies (GWAS), have been performed to identify the genetic causes of ASD. To date, hundreds to thousands of causative and susceptible genes, copy number variants (CNVs), linkage regions, and microRNAs have been associated with ASD, which clearly indicates that these are complicated genetic disorders. Not surprisingly, most of the known genetic changes alter neural function, and particularly affect neurodevelopment and 
synaptic functions. On the basis of the genetics of autism that we have learned to date, many animal models have been generated to examine the pathophysiology of ASD [13,14]. Here, we will briefly summarize some of the highconfidence genetic changes in ASD and their possible roles in the pathogenesis.

\section{Copy number variants in ASD}

Cytogenetic abnormalities have been found in every chromosome in individuals with ASD [15], and studies have reported that $\mathrm{CNVs}$, including deletions and duplications, are associated with $8 \%-20 \%$ of ASD cases [16]. Researchers use comparative genomic hybridization (array $\mathrm{CGH}$ ) to identify the copy number changes, by which technique DNA from two samples is labeled with different colors, and hybridized to specific probes to measure the differences in fluorescence intensity. $\mathrm{CGH}$ has shown that de novo $\mathrm{CNV}$ s are a significant risk factor for simplex forms of ASD [17-19]. The size of the altered chromosomal regions is from tens of kilobases to megabases, and the affected regions include 1q21, 2q24, 2q37, 2p16, 3p14, 5p14-p15, 6p23, 7p21, 10q11, 11q25, 13q14, 15q11-q13, 16q22, 20p13-p12, 22q11 and 22q13, and X-p22 [15,17-19]. Among those CNVs, 15q, $22 q$, and $7 q$ have been found fairly frequently in individuals with ASD [20-26], which is partly due to the genomic instability of these chromosomal regions [27]. Interestingly, $15 q 11-q 13$ duplication causes up to $5 \%$ of cases of autism [15,24,28-35], and 15q11-q13 deletion is involved in Angelman syndromes [36-41]. Transgenic mice with a duplication of a $6.3 \mathrm{Mb}$ chromosomal region corresponding to human 15q11-13 have been generated, and those mice with a paternal duplication show social abnormalities in the three-chamber test, decreased exploratory activity and behavioral inflexibility in the maze test, and an accompanying reduction in brain serotonin levels $[42,43]$. Further characterization of the genes located on these CNVs, by a comparison with the large amount of the putative risk genes, would shed new light on the genetics of ASD.

\section{Causal genes in ASD}

Hundreds of studies have been conducted to identify causative genes for ASD, and multiple genes have been implicated in ASD pathogenesis. Since the number of known ASD-related genes has grown so rapidly, we have chosen to focus on some of those that are the most well-defined and well-studied, and to examine their pathophysiological functions. We will divide those genes into two categories: (i) genes involved in neurodevelopment, and (ii) genes involved in neurodegeneration.

\subsection{Genes involved in neurodevelopment}

\subsubsection{Fragile $X$ mental retardation 1}

Silencing of fragile $\mathrm{X}$ mental retardation 1 (FMRI) gene expression is the major cause of fragile $\mathrm{X}$ syndrome (FXS), which is the most common form of inherited intellectual disability [44]. Individuals with FXS show mental retardation, along with autistic-like behavior, such as social and language deficits [45]. Approximately $30 \%$ of those with FXS have been diagnosed with autism, and 3\%-6\% of individuals with autism have FXS [46]. FMRI is located on the $\mathrm{X}$ chromosome, and encodes protein fragile $\mathrm{X}$ mental retardation protein (FMRP). Most people with FXS carry a trinucleotide (CGG) repeat expansion in the $5^{\prime}$ untranslated region, causing FMRl gene silencing at the transcriptional level, and loss of FMRP in neurons [47,48]. FMRP binds RNA and negatively regulates protein translation [44]. Although the exact mechanism controlling the specificity of FMRP binding mRNAs is not very clear, knockout (KO) of FMRP in mice leads to a global increase in protein synthesis [49-51]. Interestingly, among hundreds of putative mRNAs serving as FMRP targets, roughly $25 \%$ are risk genes for ASD, such as neurexin (Nrxn)-1, neuroligin (Nlgn)-3, and Src homology 3 (SH3) and multiple ankyrin repeat domains 3 (Shank3; http://gene.sfari.org).

FMRI-deficient mice show increased locomotor activity in the open-field test, elevated anxiety levels in the mirror-chamber test, and impaired social interaction with unfamiliar partners in multiple tests [52-56]. Interestingly, the FXS-like behavior phenotypes in FMRI KO mice were rescued by repressing the function of group 1 metabotropic glutamate receptors (Gp1 mGluRs). FMRl KO mice with $50 \%$ mGluR5 protein expressed in vivo resulted in the correction of seven out of the eight FXS-related phenotypes observed [49]. Furthermore, reduced mGluR5 expression also reversed cellular and synaptic phenotypes, such as increased protein synthesis, and also altered hippocampal long-term depression in the FMRI KO mice. In support of this mGluR hypothesis of Fragile X Syndrome, analysis of double KO Drosophila of $d F m r l$ (homolog of the human FMR1 gene) and dmGluRA (the Drosophila mGluR) has suggested that these two genes converge to regulate postsynaptic GluR trafficking, synaptic ultrastructure and plasticity, and motor behavior [57-59]. 2-methyl-6(phenylethynyl)-pyridine (MPEP), a potent negative modulator of mGluR5 [60], consistently rescues many FXSrelated deficits in $\mathrm{KO}$ mice [50,55,56,61-63], fly [64-66] and zebrafish [67], implying the therapeutic potential of FXS using mGluR5 inhibitors. Indeed, multiple human clinical trials with chemicals targeting mGluR5, or mGluRs- related signaling pathways, or presynaptic release of glutamate, such as gamma-aminobutyric acid $(\mathrm{GABA})_{\mathrm{B}}$ receptor agonists, are being conducted, and are showing promising, but as yet inconclusive, results with regard to treating FXS [68-71]. 
Therefore, an attempt to identify corrective treatments for FXS, the single-gene disorder associated with autism, would provide valuable information for treating more genetically heterogeneous disorders, such as ASD.

\subsubsection{Neurexins and Neuroligins}

Nrxns and Nlgns are type-I transmembrane proteins localized at the pre- and postsynaptic sites, respectively [72]. There are three Nrxns in mammals, and three (in rodents) or five (in humans) Nlgn isoforms [73]. As a synaptic adhesion molecule pair at synapses, Nrxns and Nlgns form a protein complex with high binding affinity within the synaptic cleft in an isoform- and splicing site-dependent manner [74-76]. In vivo studies have shown that Nrxns and Nlgns also play an important role in the maturation of synapses [77-80]. Inactivation of the $\alpha$-form of all three Nrxns in mice impairs presynaptic neurotransmitter release, and postsynaptic receptor function [81-83]. KO of Nlgn-1, -2, and -3 in mice causes neonatal lethality, as well as massive synaptic alterations [80].

Multiple genetic changes in Nrxn [84-94] and Nlgn genes [92,93,95-110] have been found in ASD patients. These changes include (i) point mutations, which cause frame shifts, small deletions, and missense mutations in both coding and promoter regions, (ii) distinct translocation events, and (iii) large-scale deletions of chromosomal DNA containing these gene loci. In support of these genes' involvements in ASD pathogenesis, $\mathrm{KO}$ of Nrxn-1 $\alpha$ in mice impairs social investigation and social approach behavior [111]; KO of Nlgn-4 in mice leads to impairments in social interaction and communication [112]. Introduction of an ASD-related mutation (R451C in the Nlgn-3 gene) into mice impairs social interaction, but increases spatial learning. Interestingly, $\mathrm{KO}$ of Nlgn-3 in mice has no effect on social interaction and spatial learning, suggesting that R451C might serve as a gain-of-function mutation [113,114]. In addition, Shank3, which forms a postsynaptic protein complex with Nlgns via binding to PSD-95 [115], is also associated with ASD [116-119]. Shank3 is a multi-domain scaffold protein, enriched at glutamatergic synapses, and has been associated with several neuropsychiatric disorders, including ASD and schizophrenia [120,121]. Family studies have shown that a Shank3 heterozygous mutation could lead to ASD [116]. Haploinsufficiency of Shank3 has been estimated to cause approximately $0.5 \%-0.75 \%$ of the monogenic form of autism [117,118]. The other members of the Shank protein family, Shank1 and Shank2, are also associated with ASD [122-125]. Deletion of the Shank3 PDZ domain in mice results in repetitive grooming and impaired social interaction, as well as decreased cortico-striatal synaptic transmission [126], while deletion of the ankyrin repeat domain exhibits mild autistic phenotypes and reduced glutamatergic transmission in the hippocampus [127].

Considering multiple mutations in genes encoding Shank3, Nrxns, and Nlgns together, the observations strongly suggest a synaptic failure, involving trans-synaptic interactions, in the pathogenesis of ASD [72].

\subsubsection{Methyl-CpG-binding protein 2 gene}

Mutations in the methyl-CpG-binding protein 2 gene $(M E C P 2)$ are the major cause $(>95 \%)$ of Rett syndrome (RTT) [128,129], a pervasive developmental disorder exhibiting autistic features, including poor social interactions and communications, which occur transiently during the regression period [130-132]. MECP2 duplication syndrome has overlapping phenotypes with autism and mental retardation [133-135]. The MECP2 gene is located on the $\mathrm{X}$ chromosome and functions as a transcriptional regulator. Although only a few coding mutations in MECP2 are associated with autism [136-138], one study showed that its expression was significantly reduced by approximately $40 \%$ in the prefrontal cortex of 11 out of 14 individuals with autism, and by around $30 \%$ in four of four individuals with Angelman syndrome [130]. During normal brain development, MECP2 plays a key role in neuronal morphogenesis, especially the formation of postsynaptic dendritic spines. RTT patients carrying $M E C P 2$ mutations show reduced spine numbers in the hippocampus [139], and $M E C P 2$ deficiency in mice consistently reduces the spine density in hippocampal pyramidal neurons [140-142]. MECP2 serves as a balancer in gene regulation: it binds to methylated $\mathrm{CpG}$ dinucleotides and recruits histone deacetylase 1 to inactive gene expression [143,144]; while loss of MECP2 in vivo represses the expression of thousands of genes, suggesting that it is a gene activator [145]. The exact mechanism of MECP2 as a gene activator is not yet clear, but there is evidence to show that activity-dependent phosphorylation at S80A and S421A/S424A might account for the fine-tuning of MECP2 functions [146,147].

$\mathrm{KO} /$ knockin of $M E C P 2$ in mice has been shown to recapitulate some of the RTT and ASD phenotypes. Mice expressing a RTT-related mutation of $M E C P 2\left(\mathrm{MECP}^{308}\right)$ show impaired diurnal activity and social behavior [148]. Conditional $\mathrm{KO}$ of $M E C P 2$ in hypothalamus single-minded 1 (Sim1)-expressing neurons affected social and feeding behaviors [149], and heterozygous loss of MECP2 in female mice revealed $\gamma$ and $\beta$ band abnormalities in response to an auditory stimulus, as measured by electroencephalograph (EEG) [150]. In other studies, environmental enrichment during the early, but not late, developmental stage, improved motor coordination in female $M E C P 2^{+/-}$mice, and reduced anxiety-related behavior [151-153]. Therefore, further analysis of these animal models may provide more mechanistic clues to the pathogenesis of ASD.

\subsubsection{The gamma-aminobutyric acid receptor subunit be- ta-3 (GABRB3) and other GABA receptor genes \\ The GABRB3 gene encodes the $\beta 3$ subunit of the $\mathrm{GABA}_{\mathrm{A}}$ receptor, a major postsynaptic receptor at inhibitory synap- ses in the brain. In 2002, Buxbaum et al. [154] reported the}


association of GABRB3 polymorphism with autism, using the transmission disequilibrium test in a population of 80 ASD families. Subsequent analysis reproduced the association between GABRB3 polymorphisms and ASD [155-159]. Furthermore, the GABRB3 gene is located within the $15 q 11-q 13$ region, the duplication of which is among the most frequently occurring events in people with ASD. Interestingly, one study showed that the GABRB3 gene was monoallelically expressed in autistic brain samples, whereas it was biallelically expressed in control samples [160], implying altered GABA signaling in ASD. Inactivation of $G A B R B 3$, conventionally or conditionally, in mice results in significant impairments in development, and social behaviors, and also causes stereotypical behavior [161-164].

In addition to mutations in $G A B R B 3$, genetic changes in other $\mathrm{GABA}_{\mathrm{A}}$ receptor-related genes have also been reported. Human 15q11-q13 region harbors the other two genes encoding $\mathrm{GABA}_{\mathrm{A}}$ receptor subunits; GABRA5 and GABRG3. GABRA4 and GABRB1 have also been identified as susceptible genes within Caucasians with autism [165,166]. Moreover, altered GABA levels in platelets and plasma have been observed in individuals with ASD [167,168]. Quantitative autoradiographic studies revealed a significant reduction in hippocampal $\mathrm{GABA}_{\mathrm{A}}$ receptors, but not in serotonin or $N$-methyl- $D$-aspartate receptors or in kainate receptors [169]. The aberrant expression of various $\mathrm{GABA}_{\mathrm{A}}$ receptor subunits has been repeatedly observed in multiple regions in brain specimens from people with ASD [170-173]. Although the precise contribution that the GABA system makes to ASD pathogenesis is inconclusive, it is likely that dysfunction in GABA signaling plays a significant role in causing the disease phenotype, and therefore requires further investigation.

\subsection{Genes involved in neurodegeneration}

Children with ASD usually experience a developmental regressive course during which behavioral signs of ASD occur over time [174]. For example, those with childhood disintegrative disorder, a rare form of low-functioning ASD, undergo the complete loss of certain language and social abilities that they had previously learned [175]. These phenomena of loss of previously acquired abilities can be speculated, at least in part, as being due to neurodegeneration in the developing brain. There is a growing body of evidence showing associations between ASD and neurodegeneration, including loss of neuronal cells, activation of microglia and astrocytes, and elevation of proinflammatory cytokines and oxidative stress [176,177]. Several post-mortem brain tissue studies have reported a decreased number of cerebellar Purkinje cells (PC), which function in modulating various cognitive and motor behaviors [178-180]. Using stereology and calbindin-D28k (CB) immunostaining, Whitney et al. [180] found that, in autistic groups, Purkinje neurons were generated, and migrated to their proper location in the Purkinje layer, but were subject to subsequent neurodegeneration. Moreover, gliosis (a sign of glial activation) was also reported to accompany neuronal degeneration in the cerebellum [178]. In 2005, Vargas et al. [179] examined the associations between neuronal degeneration, neuroglial activation, and neuroinflammation. Neurodegeneration and glial activation appeared to predominantly occur in the PC and granular cell layers of the cerebellum, while the active neuroinflammatory process was observed in the cerebral cortex, white matter, and cerebellum of individuals with autism. Immunocytochemical studies showed that levels of proinflammatory chemokines, and macrophage chemoattractant protein-1 were elevated. This elevation is perhaps linked to the recruitment of macrophages to areas of neurodegeneration in the cerebellum [179].

Over production of oxidative stress is a key element of some neurodegenerative disorders, such as Alzheimer's disease (AD), Parkinson's disease, and amyotrophic lateral sclerosis [181]. Studies of individuals diagnosed with an ASD, showed that, 3-nitrotyrosine, a marker of oxidative stress, was increased in a brain-region-specific manner [182,183]. In a separate study, another oxidative stress marker, lipid hydroperoxide, was significantly elevated in the cerebellum and temporal cortex during ASD [184]. In 2012, using meta-analysis method, Frustaci et al. [185] reported that for the C677T allele in the methylene tetrahydrofolate reductase (MTHFR) gene, homozygous mutant subjects (TT) showed a meta-OR of 2.26 (95\% confidence interval 1.30-3.91) of being affected by ASD with respect to the homozygous non mutant (CC). Additional single nucleotide polymorphisms (SNPs) in other genes encoding enzymes involved in oxidative stress, such as, have also been associated with a change in ASD risk from several case-control and linkage studies [186-190]. Thus, in the pathogenesis of ASD, oxidative stress may play an important role via neurodegeneration in genetically predisposed individuals.

In addition to the experimental evidence showing that neurodegeneration apparently occurs in the ASD brain, genes previously reported to be primarily involved in neurodegenerative disorders are also associated with ASD. We will summarize the evidence in this regard below.

\subsubsection{Apolipoprotein E (ApoE) and Reelin}

ApoE is a 299 amino acid glycoprotein that is primarily generated and secreted by glia in the brain. In humans, the ApoE gene shows polymorphism, which results in three different alleles: $\varepsilon 2, \varepsilon 3$, and $\varepsilon 4$, and different phenotypes ( $\varepsilon$ $2 / 2, \varepsilon 2 / 3, \varepsilon 2 / 4, \varepsilon 3 / 4$, and $\varepsilon 4 / 4$ ). It plays an important role in mediating the regular supply of neuronal lipids, and scavenging $A \beta$ peptides, as well as in the promotion of substantial neurotransmitter release [191,192]. Laboratory and epidemiologic research has consistently implicated the $A p$ $o E$ gene in the pathogenesis of late-onset sporadic AD [193], and the ApoEs4 allele significantly increases the risk in a dose-dependent manner [194]. 
In 2009, the relationship between ApoE isoforms and ASD was evaluated by an identification of its frequency of alleles and genotypes [195]. A total of 67 (56 males and 11 females) unrelated Brazilians with autism, with ages ranging from 4 to 33 years, were selected for a case-control study. It was found that the allelic and genotypic frequencies between the patients and controls were significantly different. The ApoE $\varepsilon 4$ allele was observed 30 times in those with autism $(22.3 \%)$ and 20 times in control individuals (14.9\%). The ApoE\&2 allele was observed 19 times in those with autism $(14.1 \%)$ and five times in control individuals (3.73\%). Moreover, $\varepsilon 4 / \varepsilon 4$ and $\varepsilon 2 / \varepsilon 2$ were not found in those with autism. These results suggested that the ApoE\&4 and ApoE 2 isoforms may be involved in the etiological complexity of predisposition to autism. Another study addressed the linkage between primary autism and ApoE alleles in 119 simplex Italian families, and 44 simplex and 29 multiplex Caucasian-American families [196]. A preferential transmission of $\varepsilon 2$ allele, over $\varepsilon 3$ and $\varepsilon 4$ alleles, to autistic offspring, was reported. A possible explanation is that ApoE competitively antagonized reelin binding to the ApoE receptor 2, with the ApoE2 protein variant displaying the lowest receptor binding affinity.

As described above, reelin is a secreted serine protease that is involved in the ApoE biochemical pathway, and mutations in reelin have been found in autism, AD, schizophrenia, bipolar disorder, depression, and epilepsy [197-200]. Several reelin polymorphisms have been associated with ASD, using RNA single-strand conformation polymorphism (RNA-SSCP) and DNA sequencing [201]. When comparing 95 Italian individuals with autism to 186 ethnically-matched controls, and haplotype-based haplotype relative risk in 172 complete trios from 165 families collected in Italy and in the USA, it was shown that a polymorphic GGC repeat located immediately $5^{\prime}$ of the reelin ATG initiator codon conferred vulnerability to autism. In addition, converging lines of evidence show a possible role for the Reelin (RELN) gene in ASD: (i) The RELN gene is located within the area of chromosome 7q that is linked to ASD [202,203]. (ii) In studies, mice devoid of reelin showed similar developmental alterations to the cytoarchitectonic alterations described in the brains of people with autism [204,205].

\subsubsection{Amyloid $\beta$ precursor protein (APP)}

$A P P$, located on chromosome 21 , encodes a type-I transmembrane protein and contains three major isoforms: APP695, APP751, and APP770 [206]. The latter two isoforms contain a 56 amino acid kunitz protease inhibitor (KPI) domain within their extracellular regions, while the APP695 isoform is predominantly expressed in neurons and lacks the KPI domains [207,208]. It has been suggested that APP plays a role in neurite outgrowth and synaptogenesis, cell adhesion, calcium metabolism, and neuronal protein trafficking along the axon [209].
Mutations in $A P P$, which lead to abnormal processing of the APP protein and accumulation of amyloid $\beta(\mathrm{A} \beta)$, have been implicated in cerebroarterial amyloidosis and autosomal dominant AD [210]. Numerous lines of evidence show that $\mathrm{A} \beta$ has neurotoxic effects and is deleterious to neuronal function. The amyloid cascade hypothesis indicates excessive $A \beta$ as being the initiating event in $A D$, leading to synaptic impairment and eventually dementia [211].

Functional and mechanistic links between impaired APP processing and autism have previously been reported. Frackowiak et al. [212] suggested a self-enhancing pathological process, initiated by intraneuronal deposition of $\mathrm{N}$-terminally truncated $\mathrm{A} \beta$ in children with ASD. The abnormal metabolism of APP accelerated N-truncated A $\beta$ deposition in cytoplasm, which became a source of reactive oxygen species and lipid peroxidation products. A positive feedback loop then formed as accumulation of lipid peroxidation products caused dysfunction of mitochondria and further increased $A \beta$ accumulation, thus leading to neuronal dysfunction in autism. Similar observations were reported by Wegiel et al. [213], in that the percentage of amyloid-positive neurons increases in individuals diagnosed with ASD. The increased intraneuronal amyloid was mainly composed of N-terminally truncated A $\beta$. Moreover, diffuse plaques containing $A \beta 40 / 42$ have been detected in three adults with ASD, suggesting an age-associated risk of alterations of APP processing. Sokol et al. [214] studied secreted APP, $A \beta 40$, and $A \beta 42$ in children with and without autism; children with autism showed higher levels of secreted APP and lower levels of $\mathrm{A} \beta 40$, compared with controls.

\section{Perspectives}

ASD cover a wide spectrum of neurodevelopmental disorders with genetic and phenotypic complexity. Extensive efforts have been made to identify the causative genetic changes that could explain the specific phenotype of ASD, and tens to thousands of associative CNVs and genes have been found. It is now fairly clear that no single master gene confers ASD pathogenesis, since none of these candidate genes contributes to even $1 \%$ of ASD cases [215]. Approximately $15 \%$ of ASD cases have a known genetic cause of either gene mutations or chromosomal rearrangements $[215,216]$. De novo or inherited CNVs account for up to 10\%-20\% of idiopathic ASD cases [16]. Recently, common variants (also referred as SNPs), which individually exert only small effects on ASD risk, have been shown to contribute to $40 \%-60 \%$ of idiopathic ASD cases when they are all considered together [217]. Despite the complexity in the genetics of autism, pathway and network analysis, using integrative approaches, has provided some clues that might result in a common autistic phenotype. Willsey et al. [218] adopted coexpression network analysis to identify convergent points in ASD brain, and pinpointed 
a convergence in glutamatergic neurons in layers $5 / 6$ of the human mid-fetal prefrontal and primary motor-somatosensory cortex. Parikshak et al. [219] reported that ASD genes are most associated with glutamatergic neurons in layer 2 in the adult cortex, by comparing RNA-sequence data between ASD and intellectual disability. Despite a limited number of reports, these initial studies using integrative approaches appear to provide an attractive mechanistic framework for further investigations of ASD. Taken together, given the complexity of genetics and phenotypes of ASD, efforts are required to not only identify further genetic changes, such as mutations and CNVs, but new analysis approaches are also needed to examine the huge amount of genetic data to gain better insights into the pathophysiological mechanisms of ASD.

The authors declare that they have no conflict of interest.

We sincerely apologize to the many authors whose works were not cited in this review due to space considerations. This work was supported by National Basic Research Program of China (2011CB809102, 2014CB942804, 2014BAI03B01, 2012YQ0302604), and National Natural Science Foundation of China (31222025, 31171025), and Program for New Century Excellent Talents in University of Ministry of Education of China (ZC), and the Project Sponsored by the Scientific Research Foundation for the Returned Overseas Chinese Scholars, State Education Ministry (ZC).

1 Szatmari P, Jones MB, Zwaigenbaum L, MacLean JE. Genetics of autism: overview and new directions. J Autism Dev Disord, 1998, 28: 351-368

2 Xu LM, Li JR, Huang Y, Zhao M, Tang X, Wei L. Autismkb: an evidence-based knowledgebase of autism genetics. Nucleic Acids Res, 2012, 40: D1016-D1022

3 Hallmayer J, Cleveland S, Torres A, Phillips J, Cohen B, Torigoe T, Miller J, Fedele A, Collins J, Smith K, Lotspeich L, Croen LA, Ozonoff S, Lajonchere C, Grether JK, Risch N. Genetic heritability and shared environmental factors among twin pairs with autism. Arch Gen Psychiatry, 2011, 68: 1095-1102

4 Bolton P, Macdonald H, Pickles A, Rios P, Goode S, Crowson M, Bailey A, Rutter M. A case-control family history study of autism. J Child Psychol Psychiatry, 1994, 35: 877-900

5 Ritvo ER, Jorde LB, Mason-Brothers A, Freeman BJ, Pingree C, Jones MB, McMahon WM, Petersen PB, Jenson WR, Mo A. The UCLA-university of Utah epidemiologic survey of autism: recurrence risk estimates and genetic counseling. Am J Psychiatry, 1989, 146: 1032-1036

6 Spiker D, Lotspeich L, Kraemer HC, Hallmayer J, McMahon W, Petersen PB, Nicholas P, Pingree C, Wiese-Slater S, Chiotti C, Wong DL, Dimicelli S, Ritvo E, Cavalli-Sforza LL, Ciaranello RD. Genetics of autism: characteristics of affected and unaffected children from 37 multiplex families. Am J Med Genet, 1994, 54: 27-35

7 Folstein S, Rutter M. Infantile autism: a genetic study of 21 twin pairs. J Child Psychol Psychiatry, 1977, 18: 297-321

8 Ritvo ER, Freeman BJ, Mason-Brothers A, Mo A, Ritvo AM. Concordance for the syndrome of autism in 40 pairs of afflicted twins. Am J Psychiatry, 1985, 142: 74-77

9 Steffenburg S, Gillberg C, Hellgren L, Andersson L, Gillberg IC, Jakobsson G, Bohman M. A twin study of autism in denmark, finland, iceland, norway and sweden. J Child Psychol Psychiatry, 1989, 30: 405-416

10 Bailey A, Le Couteur A, Gottesman I, Bolton P, Simonoff E, Yuzda
E, Rutter M. Autism as a strongly genetic disorder: evidence from a british twin study. Psychol Med, 1995, 25: 63-77

11 Pickles A, Bolton P, Macdonald H, Bailey A, Le Couteur A, Sim CH, Rutter M. Latent-class analysis of recurrence risks for complex phenotypes with selection and measurement error: a twin and family history study of autism. Am J Hum Genet, 1995, 57: 717-726

12 Greenberg DA, Hodge SE, Sowinski J, Nicoll D. Excess of twins among affected sibling pairs with autism: implications for the etiology of autism. Am J Hum Genet, 2001, 69: 1062-1067

13 Provenzano G, Zunino G, Genovesi S, Sgadó P, Bozzi Y. Mutant mouse models of autism spectrum disorders. Dis Markers, 2012, 33 : 225-239

14 Moy SS, Nadler JJ, Magnuson TR, Crawley JN. Mouse models of autism spectrum disorders: the challenge for behavioral genetics. Am J Med Genet C Semin Med Genet, 2006, 142C: 40-51

15 Vorstman JA, Staal WG, van Daalen E, van Engeland H, Hochstenbach PF, Franke L. Identification of novel autism candidate regions through analysis of reported cytogenetic abnormalities associated with autism. Mol Psychiatry, 2006, 11: 1, 18-28

16 Beaudet AL. Autism: highly heritable but not inherited. Nat Med, 2007, 13: 534-536

17 Jacquemont ML, Sanlaville D, Redon R, Raoul O, Cormier-Daire V, Lyonnet S, Amiel J, Le Merrer M, Heron D, de Blois MC, Prieur M, Vekemans M, Carter NP, Munnich A, Colleaux L, Philippe A. Array-based comparative genomic hybridisation identifies high frequency of cryptic chromosomal rearrangements in patients with syndromic autism spectrum disorders. J Med Genet, 2006, 43: 843-849

18 Sebat J, Lakshmi B, Malhotra D, Troge J, Lese-Martin C, Walsh T, Yamrom B, Yoon S, Krasnitz A, Kendall J, Leotta A, Pai D, Zhang R, Lee YH, Hicks J, Spence SJ, Lee AT, Puura K, Lehtimäki T, Ledbetter D, Gregersen PK, Bregman J, Sutcliffe JS, Jobanputra V, Chung W, Warburton D, King MC, Skuse D, Geschwind DH, Gilliam TC, Ye K, Wigler M. Strong association of de novo copy number mutations with autism. Science, 2007, 316: 445-449

19 Gilman SR, Iossifov I, Levy D, Ronemus M, Wigler M, Vitkup D. Rare de novo variants associated with autism implicate a large functional network of genes involved in formation and function of synapses. Neuron, 2011, 70: 898-907

20 Simon EW, Haas-Givler B, Finucane B. A longitudinal follow-up study of autistic symptoms in children and adults with duplications of 15q11-13. Am J Med Genet B Neuropsychiatr Genet, 2010, 153B: 463-467

21 Bremer A, Giacobini M, Nordenskjold M, Brøndum-Nielsen K, Mansouri M, Dahl N, Anderlid B, Schoumans J. Screening for copy number alterations in loci associated with autism spectrum disorders by two-color multiplex ligation-dependent probe amplification. Am J Med Genet B Neuropsychiatr Genet, 2010, 153B: 280-285

22 Kwasnicka-Crawford DA, Roberts W, Scherer SW. Characterization of an autism-associated segmental maternal heterodisomy of the chromosome 15q11-13 region. J Autism Dev Disord, 2007, 37: 694-702

23 Koochek M, Harvard C, Hildebrand MJ, Van Allen M, Wingert H, Mickelson E, Holden JJ, Rajcan-Separovic E, Lewis ME. 15q duplication associated with autism in a multiplex family with a familial cryptic translocation $\mathrm{t}(14 ; 15)(\mathrm{q} 11.2 ; \mathrm{q} 13.3)$ detected using array-CGH. Clin Genet, 2006, 69: 124-134

24 Bolton PF, Veltman MW, Weisblatt E, Holmes JR, Thomas NS, Youings SA, Thompson RJ, Roberts SE, Dennis NR, Browne CE, Goodson S, Moore V, Brown J. Chromosome 15q11-13 abnormalities and other medical conditions in individuals with autism spectrum disorders. Psychiatr Genet, 2004, 14: 131-137

25 Bundey S, Hardy C, Vickers S, Kilpatrick MW, Corbett JA. Duplication of the 15q11-13 region in a patient with autism, epilepsy and ataxia. Dev Med Child Neurol, 1994, 36: 736-742

26 Baker P, Piven J, Schwartz S, Patil S. Brief report: duplication of chromosome $15 q 11-13$ in two individuals with autistic disorder. $\mathrm{J}$ Autism Dev Disord, 1994, 24: 529-535

27 Emanuel BS, Shaikh TH. Segmental duplications: An "expanding" 
role in genomic instability and disease. Nat Rev Genet, 2001, 2: 791-800

28 Belmonte MK, Cook EH Jr, Anderson GM, Rubenstein JL, Greenough WT, Beckel-Mitchener A, Courchesne E, Boulanger LM, Powell SB, Levitt PR, Perry EK, Jiang YH, DeLorey TM, Tierney E. Autism as a disorder of neural information processing: directions for research and targets for therapy. Mol Psychiatry, 2004, 9: 646-663

29 Cook EH Jr, Scherer SW. Copy-number variations associated with neuropsychiatric conditions. Nature, 2008, 455: 919-923

30 Dykens EM, Sutcliffe JS, Levitt P. Autism and 15q11-q13 disorders: behavioral, genetic, and pathophysiological issues. Ment Retard Dev Disabil Res Rev, 2004, 10: 284-291

31 Folstein SE, Rosen-Sheidley B. Genetics of autism: complex aetiology for a heterogeneous disorder. Nat Rev Genet, 2001, 2: 943-955

32 Lord C, Cook EH, Leventhal BL, Amaral DG. Autism spectrum disorders. Neuron, 2000, 28: 355-363

33 Maestrini E, Paul A, Monaco AP, Bailey A. Identifying autism susceptibility genes. Neuron, 2000, 28: 19-24

34 Veenstra-Vanderweele J, Christian SL, Cook EH Jr. Autism as a paradigmatic complex genetic disorder. Annu Rev Genomics Hum Genet, 2004, 5: 379-405

35 Veenstra-VanderWeele J, Cook EH Jr. Molecular genetics of autism spectrum disorder. Mol Psychiatry, 2004, 9: 819-832

36 Nicholls RD, Knepper JL. Genome organization, function, and imprinting in Prader-Willi and Angelman syndromes. Annu Rev Genomics Hum Genet, 2001, 2: 153-175

37 Valente KD, Varela MC, Koiffmann CP, Andrade JQ, Grossmann R, Kok F, Marques-Dias MJ. Angelman syndrome caused by deletion: a genotype-phenotype correlation determined by breakpoint. Epilepsy Res, 2013, 105: 234-239

38 Kuwano A, Mutirangura A, Dittrich B, Buiting K, Horsthemke B, Saitoh S, Niikawa N, Ledbetter SA, Greenberg F, Chinault AC, Ledbetter DH. Molecular dissection of the Prader-Willi/Angelman syndrome region (15q11-13) by YAC cloning and FISH analysis. Hum Mol Genet, 1992, 1: 417-425

39 Wagstaff J, Knoll JH, Glatt KA, Shugart YY, Sommer A, Lalande M. Maternal but not paternal transmission of 15q11-13-linked nondeletion angelman syndrome leads to phenotypic expression. Nat Genet, 1992, 1: 291-294

40 Pembrey M, Fennell SJ, van den Berghe J, Fitchett M, Summers D, Butler L, Clarke C, Griffiths M, Thompson E, Super M. The association of Angelman's syndrome with deletions within 15q11-13. J Med Genet, 1989, 26: 73-77

41 Smith JC, Webb T, Pembrey ME, Nichols M, Malcolm S. Maternal origin of deletion $15 q 11-13$ in 25/25 cases of angelman syndrome. Hum Genet, 1992, 88: 376-378

42 Tamada K, Tomonaga S, Hatanaka F, Nakai N, Takao K, Miyakawa T, Nakatani J, Takumi T. Decreased exploratory activity in a mouse model of $15 q$ duplication syndrome; implications for disturbance of serotonin signaling. PLoS One, 2010, 5: e15126

43 Nakatani J, Tamada K, Hatanaka F, Ise S, Ohta H, Inoue K, Tomonaga S, Watanabe Y, Chung YJ, Banerjee R, Iwamoto K, Kato T, Okazawa M, Yamauchi K, Tanda K, Takao K, Miyakawa T, Bradley A, Takumi T. Abnormal behavior in a chromosomeengineered mouse model for human 15q11-13 duplication seen in autism. Cell, 2009, 137: 1235-1246

44 Bhakar AL, Dolen G, Bear MF. The pathophysiology of fragile X (and what it teaches us about synapses). Annu Rev Neurosci, 2012, 35: 417-443

45 Hagerman RJ, Jackson AW 3rd, Levitas A, Rimland B, Braden M. An analysis of autism in fifty males with the fragile $\mathrm{X}$ syndrome. Am J Med Genet, 1986, 23: 359-374

46 Wang LW, Berry-Kravis E, Hagerman RJ. Fragile X: leading the way for targeted treatments in autism. Neurotherapeutics, 2010, 7: 264-274

47 Fu YH, Kuhl DP, Pizzuti A, Pieretti M, Sutcliffe JS, Richards S, Verkerk AJ, Holden JJ, Fenwick RG Jr, Warren ST, Oostra BA, Nelson DL, Thomas Caskey C. Variation of the CGG repeat at the fragile X site results in genetic instability: resolution of the Sherman paradox. Cell, 1991, 67: 1047-1058

48 Pieretti M, Zhang FP, Fu YH, Warren ST, Oostra BA, Caskey CT, Nelson DL. Absence of expression of the FMR-1 gene in fragile $\mathrm{X}$ syndrome. Cell, 1991, 66: 817-822

49 Dolen G, Osterweil E, Rao BS, Smith GB, Auerbach BD, Chattarji S, Bear MF. Correction of fragile X syndrome in mice. Neuron, 2007, 56: $955-962$

50 Osterweil EK, Krueger DD, Reinhold K, Bear MF. Hypersensitivity to mGluR5 and ERK1/2 leads to excessive protein synthesis in the hippocampus of a mouse model of fragile X syndrome. J Neurosci, 2010, 30: 15616-15627

51 Liu ZH, Huang T, Smith CB. Lithium reverses increased rates of cerebral protein synthesis in a mouse model of fragile $\mathrm{X}$ syndrome. Neurobiol Dis, 2012, 45: 1145-1152

52 Thomas AM, Bui N, Graham D, Perkins JR, Yuva-Paylor LA, Paylor R. Genetic reduction of group 1 metabotropic glutamate receptors alters select behaviors in a mouse model for fragile $\mathrm{X}$ syndrome. Behav Brain Res, 2011, 223: 310-321

53 Spencer CM, Alekseyenko O, Serysheva E, Yuva-Paylor LA, Paylor R. Altered anxiety-related and social behaviors in the FMRI knockout mouse model of fragile X syndrome. Genes Brain Behav, 2005, 4: 420-430

54 Spencer CM, Graham DF, Yuva-Paylor LA, Nelson DL, Paylor R. Social behavior in Fmrl knockout mice carrying a human FMRI transgene. Behav Neurosci, 2008, 122: 710-715

55 Min WW, Yuskaitis CJ, Yan Q, Sikorski C, Chen S, Jope RS, Bauchwitz RP. Elevated glycogen synthase kinase-3 activity in Fragile X mice: key metabolic regulator with evidence for treatment potential. Neuropharmacology, 2009, 56: 463-472

56 Yan QJ, Rammal M, Tranfaglia M, Bauchwitz RP. Suppression of two major Fragile X Syndrome mouse model phenotypes by the mGluR5 antagonist MPEP. Neuropharmacology, 2005, 49: 1053-1066

57 Pan L, Broadie KS. Drosophila fragile X mental retardation protein and metabotropic glutamate receptor A convergently regulate the synaptic ratio of ionotropic glutamate receptor subclasses. J Neurosci, 2007, 27: 12378-12389

58 Pan L, Woodruff E 3rd, Liang P, Broadie K. Mechanistic relationships between Drosophila Fragile $\mathrm{X}$ mental retardation protein and metabotropic glutamate receptor A signaling. Mol Cell Neurosci, 2008, 37: 747-760

59 Repicky S, Broadie K. Metabotropic glutamate receptor-mediated use-dependent down-regulation of synaptic excitability involves the Fragile X mental retardation protein. J Neurophysiol, 2009, 101: 672-687

60 Gasparini F, Lingenhohl K, Stoehr N, Flor PJ, Heinrich M, Vranesic I, Biollaz M, Allgeier H, Heckendorn R, Urwyler S, Varney MA, Johnson EC, Hess SD, Rao SP, Sacaan AI, Santori EM, Veliçelebi G, Kuhn R. 2-methyl-6-(phenylethynyl)-pyridine (MPEP), a potent, selective and systemically active mGlu5 receptor antagonist. Neuropharmacology, 1999, 38: 1493-1503

61 Chuang SC, Zhao W, Bauchwitz R, Yan Q, Bianchi R, Wong RK. Prolonged epileptiform discharges induced by altered group I metabotropic glutamate receptor-mediated synaptic responses in hippocampal slices of a fragile X mouse model. J Neurosci, 2005, 25: 8048-8055

62 de Vrij FM, Levenga J, van der Linde HC, Koekkoek SK, De Zeeuw CI, Nelson DL, Oostra BA, Willemsen R. Rescue of behavioral phenotype and neuronal protrusion morphology in Fmrl KO mice. Neurobiol Dis, 2008, 31: 127-132

63 Aschrafi A, Cunningham BA, Edelman GM, Vanderklish PW. The fragile $\mathrm{X}$ mental retardation protein and group I metabotropic glutamate receptors regulate levels of mRNA granules in brain. Proc Natl Acad Sci USA, 2005, 102: 2180-2185

64 McBride SM, Choi CH, Wang Y, Liebelt D, Braunstein E, Ferreiro D, Sehgal A, Siwicki KK, Dockendorff TC, Nguyen HT, McDonald TV, Jongens TA. Pharmacological rescue of synaptic plasticity, courtship behavior, and mushroom body defects in a Drosophila model of 
fragile X syndrome. Neuron, 2005, 45: 753-764

65 Bolduc FV, Bell K, Cox H, Broadie KS, Tully T. Excess protein synthesis in Drosophila fragile X mutants impairs long-term memory. Nat Neurosci, 2008, 11: 1143-1145

66 Chang S, Bray SM, Li Z, Zarnescu DC, He C, Jin P, Warren ST. Identification of small molecules rescuing fragile $\mathrm{X}$ syndrome phenotypes in Drosophila. Nat Chem Biol, 2008, 4: 256-263

67 Tucker B, Richards RI, Lardelli M. Contribution of mGluR and Fmr1 functional pathways to neurite morphogenesis, craniofacial development and fragile X syndrome. Hum Mol Genet, 2006, 15: 3446-3458

68 Krueger DD, Bear MF. Toward fulfilling the promise of molecular medicine in fragile X syndrome. Annu Rev Med, 2011, 62: 411-429

69 Jacquemont S, Berry-Kravis E, Hagerman R, von Raison F, Gasparini F, Apostol G, Ufer M, Des Portes V, Gomez-Mancilla B. The challenges of clinical trials in fragile $\mathrm{X}$ syndrome. Psychopharmacology (Berl), 2014, 231: 1237-1250

70 Pop AS, Gomez-Mancilla B, Neri G, Willemsen R, Gasparini F. Fragile X syndrome: a preclinical review on metabotropic glutamate receptor 5 (mGluR5) antagonists and drug development. Psychopharmacology (Berl), 2014, 231: 1217-1226

71 Ghosh A, Michalon A, Lindemann L, Fontoura P, Santarelli L. Drug discovery for autism spectrum disorder: challenges and opportunities. Nat Rev Drug Discov, 2013, 12: 777-790

72 Sudhof TC. Neuroligins and neurexins link synaptic function to cognitive disease. Nature, 2008, 455: 903-911

73 Lise MF, El-Husseini A. The neuroligin and neurexin families: from structure to function at the synapse. Cell Mol Life Sci, 2006, 63: 1833-1849

74 Comoletti D, Flynn RE, Boucard AA, Demeler B, Schirf V, Shi J, Jennings LL, Newlin HR, Südhof TC, Taylor P. Gene selection, alternative splicing, and post-translational processing regulate neuroligin selectivity for $\beta$-neurexins. Biochemistry, 2006, 45: 12816-12827

75 Arac D, Boucard AA, Ozkan E, Strop P, Newell E, Südhof TC, Brunger AT. Structures of neuroligin-1 and the neuroligin-1/ neurexin- $1 \beta$ complex reveal specific protein-protein and protein-Ca ${ }^{2+}$ interactions. Neuron, 2007, 56: 992-1003

76 Boucard AA, Chubykin AA, Comoletti D, Taylor P, Südhof TC. A splice code for trans-synaptic cell adhesion mediated by binding of neuroligin 1 to $\alpha$ - and $\beta$-neurexins. Neuron, 2005, 48: 229-236

77 Chubykin AA, Atasoy D, Etherton MR, Brose N, Kavalali ET, Gibson JR, Südhof TC. Activity-dependent validation of excitatory versus inhibitory synapses by neuroligin-1 versus neuroligin-2. Neuron, 2007, 54: 919-931

78 Zhang C, Atasoy D, Arac D, Yang X, Fucillo MV, Robison AJ, Ko J, Brunger AT, Südhof TC. Neurexins physically and functionally interact with $\mathrm{GABA}_{\mathrm{A}}$ receptors. Neuron, 2010, 66: 403-416

79 Ko J, Soler-Llavina GJ, Fuccillo MV, Malenka RC, Südhof TC. Neuroligins/LRRTMs prevent activity- and $\mathrm{Ca}^{2+} /$ calmodulindependent synapse elimination in cultured neurons. J Cell Biol, 2011, 194: 323-334

80 Varoqueaux F, Aramuni G, Rawson RL, Mohrmann R, Missler M, Gottmann K, Zhang W, Südhof TC, Brose N. Neuroligins determine synapse maturation and function. Neuron, 2006, 51: 741-754

81 Zhang W, Rohlmann A, Sargsyan V, Aramuni G, Hammer RE, Südhof TC, Missler M. Extracellular domains of alpha-neurexins participate in regulating synaptic transmission by selectively affecting $\mathrm{N}$ - and P/Q-type $\mathrm{Ca}^{2+}$ channels. J Neurosci, 2005, 25: 4330-4342

82 Missler M, Zhang W, Rohlmann A, Kattenstroth G, Hammer RE, Gottmann K, Südhof TC. $\alpha$-neurexins couple $\mathrm{Ca}^{2+}$ channels to synaptic vesicle exocytosis. Nature, 2003, 423: 939-948

83 Kattenstroth G, Tantalaki E, Sudhof TC, Gottmann K, Missler M. Postsynaptic $N$-methyl-D-aspartate receptor function requires $\alpha$-neurexins. Proc Natl Acad Sci USA, 2004, 101: 2607-2612

84 Yan J, Noltner K, Feng J, Li W, Schroer R, Skinner C, Zeng W, chwartz CE, Sommer SS. Neurexin $1 \alpha$ structural variants associated with autism. Neurosci Lett, 2008, 438: 368-370

85 Feng J, Schroer R, Yan J, Song W, Yang C, Bockholt A, Cook EH Jr, Skinner C, Schwartz CE, Sommer SS. High frequency of neurexin $1 \beta$ signal peptide structural variants in patients with autism. Neurosci Lett, 2006, 409: 10-13

86 Camacho-Garcia RJ, Hervas A, Toma C, Balmaña N, Cormand B, Martinez-Mir A, Scholl FG. Rare variants analysis of neurexin- $1 \beta$ in autism reveals a novel start codon mutation affecting protein levels at synapses. Psychiatr Genet, 2013, 23: 262-266

87 Bena F, Bruno DL, Eriksson M, van Ravenswaaij-Arts C, Stark Z, Dijkhuizen T, Gerkes E, Gimelli S, Ganesamoorthy D, Thuresson AC, Labalme A, Till M, Bilan F, Pasquier L, Kitzis A, Dubourgm C, Rossi M, Bottani A, Gagnebin M, Sanlaville D, Gilbert-Dussardier B, Guipponi M, van Haeringen A, Kriek M, Ruivenkamp C, Antonarakis SE, Anderlid BM, Slater HR, Schoumans J. Molecular and clinical characterization of 25 individuals with exonic deletions of NRXN1 and comprehensive review of the literature. Am J Med Genet B Neuropsychiatr Genet, 2013, 162B: 388-403

88 Schaaf CP, Boone PM, Sampath S, Williams C, Bader PI, Mueller JM, Shchelochkov OA, Brown CW, Crawford HP, Phalen JA, Tartaglia NR, Evans P, Campbell WM, Tsai AC, Parsley L, Grayson SW, Scheuerle A, Luzzi CD, Thomas SK, Eng PA, Kang SH, Patel A, Stankiewicz P, Cheung SW. Phenotypic spectrum and genotypephenotype correlations of NRXN1 exon deletions. Eur J Hum Genet, 2012, 20: 1240-1247

89 Liu Y, Hu Z, Xun G, Peng Y, Lu L, Xu X, Xiong Z, Xia L, Liu D, Li $\mathrm{W}$, Zhao J, Xia K. Mutation analysis of the NRXN1 gene in a Chinese autism cohort. J Psychiatr Res, 2012, 46: 630-634

90 Zweier C, de Jong EK, Zweier M, Orrico A, Ousager LB, Collins AL, Bijlsma EK, Oortveld MA, Ekici AB, Reis A, Schenck A, Rauch A. CNTNAP2 and NRXN1 are mutated in autosomal-recessive Pitt-Hopkins-like mental retardation and determine the level of a common synaptic protein in Drosophila. Am J Hum Genet, 2009, 85: 655-666

91 Autism Genome Project Consortium, Szatmari P, Paterson AD, Zwaigenbaum L, Roberts W, Brian J, Liu XQ, Vincent JB, Skaug JL, Thompson AP, Senman L, Feuk L, Qian C, Bryson SE, Jones MB, Marshall CR, Scherer SW, Vieland VJ, Bartlett C, Mangin LV, Goedken R, Segre A, Pericak-Vance MA, Cuccaro ML, Gilbert JR, Wright HH, Abramson RK, Betancur C, Bourgeron T, Gillberg C, Leboyer M, Buxbaum JD, Davis KL, Hollander E, Silverman JM, Hallmayer J, Lotspeich L, Sutcliffe JS, Haines JL, Folstein SE, Piven J, Wassink TH, Sheffield V, Geschwind DH, Bucan M, Brown WT, Cantor RM, Constantino JN, Gilliam TC, Herbert M, Lajonchere C, Ledbetter DH, Lese-Martin C, Miller J, Nelson S, Samango-Sprouse CA, Spence S, State M, Tanzi RE, Coon H, Dawson G, Devlin B, Estes A, Flodman P, Klei L, McMahon WM, Minshew N, Munson J, Korvatska E, Rodier PM, Schellenberg GD, Smith M, Spence MA, Stodgell C, Tepper PG, Wijsman EM, Yu CE, Rogé B, Mantoulan C, Wittemeyer K, Poustka A, Felder B, Klauck SM, Schuster C, Poustka F, Bölte S, Feineis-Matthews S, Herbrecht E, Schmötzer G, Tsiantis J, Papanikolaou K, Maestrini E, Bacchelli E, Blasi F, Carone S, Toma C, Van Engeland H, de Jonge M, Kemner C, Koop F, Langemeijer M, Hijmans C, Staal WG, Baird G, Bolton PF, Rutter ML, Weisblatt E, Green J, Aldred C, Wilkinson JA, Pickles A, Le Couteur A, Berney T, McConachie H, Bailey AJ, Francis K, Honeyman G, Hutchinson A, Parr JR, Wallace S, Monaco AP, Barnby G, Kobayashi K, Lamb JA, Sousa I, Sykes N, Cook EH, Guter SJ, Leventhal BL, Salt J, Lord C, Corsello C, Hus V, Weeks DE, Volkmar F, Tauber M, Fombonne E, Shih A, Meyer KJ. Mapping autism risk loci using genetic linkage and chromosomal rearrangements. Nat Genet, 2007, 39: 319-328

92 Marshall CR, Noor A, Vincent JB, Lionel AC, Feuk L, Skaug J, Shago M, Moessner R, Pinto D, Ren Y, Thiruvahindrapduram B, Fiebig A, Schreiber S, Friedman J, Ketelaars CE, Vos YJ, Ficicioglu C, Kirkpatrick S, Nicolson R, Sloman L, Summers A, Gibbons CA, Teebi A, Chitayat D, Weksberg R, Thompson A, Vardy C, Crosbie V, Luscombe S, Baatjes R, Zwaigenbaum L, Roberts W, Fernandez B, Szatmari P, Scherer SW. Structural variation of chromosomes in 
autism spectrum disorder. Am J Hum Genet, 2008, 82: 477-488

93 Morrow EM, Yoo SY, Flavell SW, Kim TK, Lin Y, Hill RS, Mukaddes NM, Balkhy S, Gascon G, Hashmi A, Al-Saad S, Ware J, Joseph RM, Greenblatt R, Gleason D, Ertelt JA, Apse KA, Bodell A, Partlow JN, Barry B, Yao H, Markianos K, Ferland RJ, Greenberg ME, Walsh CA. Identifying autism loci and genes by tracing recent shared ancestry. Science, 2008, 321: 218-223

94 Camacho-Garcia RJ, Planelles MI, Margalef M, Pecero ML, Martínez-Leal R, Aguilera F, Vilella E, Martinez-Mir A, Scholl FG. Mutations affecting synaptic levels of neurexin- $1 \beta$ in autism and mental retardation. Neurobiol Dis, 2012, 47: 135-143

95 Laumonnier F, Bonnet-Brilhault F, Gomot M, Blanc R, David A, Moizard MP, Raynaud M, Ronce N, Lemonnier E, Calvas P, Laudier B, Chelly J, Fryns JP, Ropers HH, Hamel BC, Andres C, Barthélémy $\mathrm{C}$, Moraine $\mathrm{C}$, Briault S. X-linked mental retardation and autism are associated with a mutation in the NLGN4 gene, a member of the neuroligin family. Am J Hum Genet, 2004, 74: 552-557

96 Jamain S, Quach H, Betancur C, Råstam M, Colineaux C, Gillberg IC, Soderstrom H, Giros B, Leboyer M, Gillberg C, Bourgeron T; Paris Autism Research International Sibpair Study. Mutations of the X-linked genes encoding neuroligins NLGN3 and NLGN4 are associated with autism. Nat Genet, 2003, 34: 27-29

97 Zhang C, Milunsky JM, Newton S, Ko J, Zhao G, Maher TA, Tager-Flusberg H, Bolliger MF, Carter AS, Boucard AA, Powell CM, Südhof TC. A neuroligin-4 missense mutation associated with autism impairs neuroligin-4 folding and endoplasmic reticulum export. J Neurosci, 2009, 29: 10843-10854

98 Avdjieva-Tzavella DM, Todorov TP, Todorova AP, Kirov AV, Hadjidekova SP, Rukova BB, Litvinenko IO, Hristova-Naydenova DN, Tincheva RS, Toncheva DI. Analysis of the genes encoding neuroligins NLGN3 and NLGN4 in Bulgarian patients with autism. Genet Couns, 2012, 23: 505-511

99 Chih B, Afridi SK, Clark L, Scheiffele P. Disorder-associated mutations lead to functional inactivation of neuroligins. Hum Mol Genet, 2004, 13: 1471-1477

100 Yan J, Oliveira G, Coutinho A, Yang C, Feng J, Katz C, Sram J, Bockholt A, Jones IR, Craddock N, Cook EH Jr, Vicente A, Sommer SS. Analysis of the neuroligin 3 and 4 genes in autism and other neuropsychiatric patients. Mol Psychiatry, 2005, 10: 329-332

101 Yanagi K, Kaname T, Wakui K, Hashimoto O, Fukushima Y, Naritomi K. Identification of four novel synonymous substitutions in the $\mathrm{X}$-linked genes neuroligin 3 and neuroligin $4 X$ in Japanese patients with autistic spectrum disorder. Autism Res Treat, 2012, 2012: 724072

102 Millson A, Lagrave D, Willis MJ, Rowe LR, Lyon E, South ST. Chromosomal loss of 3q26.3-3q26.32, involving a partial neuroligin 1 deletion, identified by genomic microarray in a child with microcephaly, seizure disorder, and severe intellectual disability. Am J Med Genet A, 2012, 158A: 159-165

103 Pampanos A, Volaki K, Kanavakis E, Papandreou O, Youroukos S, Thomaidis L, Karkelis S, Tzetis M, Kitsiou-Tzeli S. A substitution involving the NLGN4 gene associated with autistic behavior in the Greek population. Genet Test Mol Biomarkers, 2009, 13: 611-615

104 Daoud H, Bonnet-Brilhault F, Védrine S, Demattéi MV, Vourc'h P, Bayou N, Andres CR, Barthélémy C, Laumonnier F, Briault S. Autism and nonsyndromic mental retardation associated with a de novo mutation in the $N L G N 4 X$ gene promoter causing an increased expression level. Biol Psychiatry, 2009, 66: 906-910

105 Yan J, Feng J, Schroer R, Li W, Skinner C, Schwartz CE, Cook EH $\mathrm{Jr}$, Sommer SS. Analysis of the neuroligin $4 Y$ gene in patients with autism. Psychiatr Genet, 2008, 18: 204-207

106 Lawson-Yuen A, Saldivar JS, Sommer S, Picker J. Familial deletion within NLGN4 associated with autism and tourette syndrome. Eur J Hum Genet, 2008, 16: 614-618

107 Macarov M, Zeigler M, Newman JP, Strich D, Sury V, Tennenbaum A, Meiner V. Deletions of VCX-A and NLGN4: a variable phenotype including normal intellect. J Intellect Disabil Res, 2007, 51: 329-333

108 Chocholska S, Rossier E, Barbi G, Kehrer-Sawatzki H. Molecular cytogenetic analysis of a familial interstitial deletion Xp22.2-22.3 with a highly variable phenotype in female carriers. Am J Med Genet A, 2006, 140: 604-610

109 Roberts JL, Hovanes K, Dasouki M, Manzardo AM, Butler MG. Chromosomal microarray analysis of consecutive individuals with autism spectrum disorders or learning disability presenting for genetic services. Gene, 2014, 535: 70-78

110 Talebizadeh Z, Lam DY, Theodoro MF, Bittel DC, Lushington GH, Butler MG. Novel splice isoforms for NLGN3 and NLGN4 with possible implications in autism. J Med Genet, 2006, 43: e21

111 Grayton HM, Missler M, Collier DA, Fernandes C. Altered social behaviours in neurexin $1 \alpha$ knockout mice resemble core symptoms in neurodevelopmental disorders. PLoS One, 2013, 8: e67114

112 Jamain S, Radyushkin K, Hammerschmidt K, Granon S, Boretius S, Varoqueaux F, Ramanantsoa N, Gallego J, Ronnenberg A, Winter D, Frahm J, Fischer J, Bourgeron T, Ehrenreich H, Brose N. Reduced social interaction and ultrasonic communication in a mouse model of monogenic heritable autism. Proc Natl Acad Sci USA, 2008, 105: 1710-1715

113 Foldy C, Malenka RC, Sudhof TC. Autism-associated neuroligin-3 mutations commonly disrupt tonic endocannabinoid signaling. Neuron, 2013, 78: 498-509

114 Tabuchi K, Blundell J, Etherton MR, Hammer RE, Liu X, Powell CM, Südhof TC. A neuroligin-3 mutation implicated in autism increases inhibitory synaptic transmission in mice. Science, 2007, 318: 71-76

115 Naisbitt S, Kim E, Tu JC, Xiao B, Sala C, Valtschanoff J, Weinberg RJ, Worley PF, Sheng M. Shank, a novel family of postsynaptic density proteins that binds to the NMDA receptor/PSD-95/GKAP complex and cortactin. Neuron, 1999, 23: 569-582

116 Durand CM, Betancur C, Boeckers TM, Bockmann J, Chaste P, Fauchereau F, Nygren G, Rastam M, Gillberg IC, Anckarsäter H, Sponheim E, Goubran-Botros H, Delorme R, Chabane N, Mouren-Simeoni MC, de Mas P, Bieth E, Rogé B, Héron D, Burglen L, Gillberg C, Leboyer M, Bourgeron T. Mutations in the gene encoding the synaptic scaffolding protein SHANK3 are associated with autism spectrum disorders. Nat Genet, 2007, 39: 25-27

117 Moessner R, Marshall CR, Sutcliffe JS, Skaug J, Pinto D, Vincent J, Zwaigenbaum L, Fernandez B, Roberts W, Szatmari P, Scherer SW. Contribution of SHANK3 mutations to autism spectrum disorder. Am J Hum Genet, 2007, 81: 1289-1297

118 Gauthier J, Spiegelman D, Piton A, Lafrenière RG, Laurent S, St-Onge J, Lapointe L, Hamdan FF, Cossette P, Mottron L, Fombonne E, Joober R, Marineau C, Drapeau P, Rouleau GA. Novel de novo SHANK3 mutation in autistic patients. Am J Med Genet B Neuropsychiatr Genet, 2009, 150B: 421-424

119 Waga C, Okamoto N, Ondo Y, Fukumura-Kato R, Goto Y, Kohsaka $\mathrm{S}$, Uchino S. Novel variants of the SHANK3 gene in Japanese autistic patients with severe delayed speech development. Psychiatr Genet, 2011, 21: 208-211

120 Guilmatre A, Huguet G, Delorme R, Bourgeron T. The emerging role of SHANK genes in neuropsychiatric disorders. Dev Neurobiol, 2014, 74: $113-122$

121 Uchino S, Waga C. SHANK3 as an autism spectrum disorder-associated gene. Brain Dev, 2013, 35: 106-110

122 Pinto D, Pagnamenta AT, Klei L, Anney R, Merico D, Regan R, Conroy J, Magalhaes TR, Correia C, Abrahams BS, Almeida J, Bacchelli E, Bader GD, Bailey AJ, Baird G, Battaglia A, Berney T, Bolshakova N, Bölte S, Bolton PF, Bourgeron T, Brennan S, Brian J, Bryson SE, Carson AR, Casallo G, Casey J, Chung BH, Cochrane L, Corsello C, Crawford EL, Crossett A, Cytrynbaum C, Dawson G, de Jonge M, Delorme R, Drmic I, Duketis E, Duque F, Estes A, Farrar P, Fernandez BA, Folstein SE, Fombonne E, Freitag CM, Gilbert J, Gillberg C, Glessner JT, Goldberg J, Green A, Green J, Guter SJ, Hakonarson H, Heron EA, Hill M, Holt R, Howe JL, Hughes G, Hus V, Igliozzi R, Kim C, Klauck SM, Kolevzon A, Korvatska O, Kustanovich V, Lajonchere CM, Lamb JA, Laskawiec M, Leboyer M, Le Couteur A, Leventhal BL, Lionel AC, Liu XQ, Lord C, Lotspeich 
L, Lund SC, Maestrini E, Mahoney W, Mantoulan C, Marshall CR, McConachie H, McDougle CJ, McGrath J, McMahon WM, Merikangas A, Migita O, Minshew NJ, Mirza GK, Munson J, Nelson SF, Noakes C, Noor A, Nygren G, Oliveira G, Papanikolaou K, Parr JR, Parrini B, Paton T, Pickles A, Pilorge M, Piven J, Ponting CP, Posey DJ, Poustka A, Poustka F, Prasad A, Ragoussis J, Renshaw K, Rickaby J, Roberts W, Roeder K, Roge B, Rutter ML, Bierut LJ, Rice JP, Salt J, Sansom K, Sato D, Segurado R, Sequeira AF, Senman L, Shah N, Sheffield VC, Soorya L, Sousa I, Stein O, Sykes N, Stoppioni V, Strawbridge C, Tancredi R, Tansey K, Thiruvahindrapduram B, Thompson AP, Thomson S, Tryfon A, Tsiantis J, Van Engeland H, Vincent JB, Volkmar F, Wallace S, Wang K, Wang Z, Wassink TH, Webber C, Weksberg R, Wing K, Wittemeyer K, Wood S, Wu J, Yaspan BL, Zurawiecki D, Zwaigenbaum L, Buxbaum JD, Cantor RM, Cook EH, Coon H, Cuccaro ML, Devlin B, Ennis S, Gallagher L, Geschwind DH, Gill M, Haines JL, Hallmayer J, Miller J, Monaco AP, Nurnberger JI Jr, Paterson AD, Pericak-Vance MA, Schellenberg GD, Szatmari P, Vicente AM, Vieland VJ, Wijsman EM, Scherer SW, Sutcliffe JS, Betancur C. Functional impact of global rare copy number variation in autism spectrum disorders. Nature, 2010, 466: 368-372

123 Berkel S, Marshall CR, Weiss B, Howe J, Roeth R, Moog U, Endris V, Roberts W, Szatmari P, Pinto D, Bonin M, Riess A, Engels H, Sprengel R, Scherer SW, Rappold GA. Mutations in the SHANK2 synaptic scaffolding gene in autism spectrum disorder and mental retardation. Nat Genet, 2010, 42: 489-491

124 Leblond CS, Heinrich J, Delorme R, Proepper C, Betancur C, Huguet G, Konyukh M, Chaste P, Ey E, Rastam M, Anckarsäter H, Nygren G, Gillberg IC, Melke J, Toro R, Regnault B, Fauchereau F, Mercati O, Lemière N, Skuse D, Poot M, Holt R, Monaco AP, Järvelä I, Kantojärvi K, Vanhala R, Curran S, Collier DA, Bolton $\mathrm{P}$, Chiocchetti A, Klauck SM, Poustka F, Freitag CM, Waltes R, Kopp M, Duketis E, Bacchelli E, Minopoli F, Ruta L, Battaglia A, Mazzone L, Maestrini E, Sequeira AF, Oliveira B, Vicente A, Oliveira G, Pinto D, Scherer SW, Zelenika D, Delepine M, Lathrop M, Bonneau D, Guinchat V, Devillard F, Assouline B, Mouren MC, Leboyer M, Gillberg C, Boeckers TM, Bourgeron T. Genetic and functional analyses of SHANK2 mutations suggest a multiple hit model of autism spectrum disorders. PLoS Genet, 2012, 8: e1002521

125 Sato D, Lionel AC, Leblond CS, Prasad A, Pinto D, Walker S, O'Connor I, Russell C, Drmic IE, Hamdan FF, Michaud JL, Endris V, Roeth R, Delorme R, Huguet G, Leboyer M, Rastam M, Gillberg C, Lathrop M, Stavropoulos DJ, Anagnostou E, Weksberg R, Fombonne E, Zwaigenbaum L, Fernandez BA, Roberts W, Rappold GA, Marshall CR, Bourgeron T, Szatmari P, Scherer SW. SHANK1 deletions in males with autism spectrum disorder. Am J Hum Genet, 2012, 90: 879-887

126 Peca J, Feliciano C, Ting JT, Wang W, Wells MF, Venkatraman TN, Lascola CD, Fu Z, Feng G. Shank3 mutant mice display autistic-like behaviours and striatal dysfunction. Nature, 2011, 472: 437-442

127 Yang M, Bozdagi O, Scattoni ML, Wöhr M, Roullet FI, Katz AM, Abrams DN, Kalikhman D, Simon H, Woldeyohannes L, Zhang JY, Harris MJ, Saxena R, Silverman JL, Buxbaum JD, Crawley JN. Reduced excitatory neurotransmission and mild autism-relevant phenotypes in adolescent Shank3 null mutant mice. J Neurosci, 2012, 32: $6525-6541$

128 Neul JL, Kaufmann WE, Glaze DG, Christodoulou J, Clarke AJ, Bahi-Buisson N, Leonard H, Bailey ME, Schanen NC, Zappella M, Renieri A, Huppke P, Percy AK; RettSearch Consortium. Rett syndrome: revised diagnostic criteria and nomenclature. Ann Neurol, 2010, 68: 944-950

129 Amir RE, Van den Veyver IB, Wan M, Tran CQ, Francke U, Zoghbi HY. Rett syndrome is caused by mutations in X-linked MECP2, encoding methyl-CpG-binding protein 2. Nat Genet, 1999, 23: $185-188$

130 Nagarajan RP, Hogart AR, Gwye Y, Martin MR, LaSalle JM. Reduced MeCP2 expression is frequent in autism frontal cortex and correlates with aberrant MECP2 promoter methylation. Epigenetics, 2006, 1: e1-e11
131 Percy AK. Rett syndrome: exploring the autism link. Arch Neurol, 2011, 68: 985-989

132 Castro J, Mellios N, Sur M. Mechanisms and therapeutic challenges in autism spectrum disorders: insights from rett syndrome. Curr Opin Neurol, 2013, 26: 154-159

133 Van Esch H, Bauters M, Ignatius J, Jansen M, Raynaud M, Hollanders K, Lugtenberg D, Bienvenu T, Jensen LR, Gecz J, Moraine C, Marynen P, Fryns JP, Froyen G. Duplication of the $M E C P 2$ region is a frequent cause of severe mental retardation and progressive neurological symptoms in males. Am J Hum Genet, 2005, 77: 442-453

134 Meins M, Lehmann J, Gerresheim F, Herchenbach J, Hagedorn M, Hameister K, Epplen JT. Submicroscopic duplication in Xq28 causes increased expression of the $M E C P 2$ gene in a boy with severe mental retardation and features of Rett syndrome. J Med Genet, 2005, 42: $\mathrm{e} 12$

135 del Gaudio D, Fang P, Scaglia F, Ward PA, Craigen WJ, Glaze DG, Neul JL, Patel A, Lee JA, Irons M, Berry SA, Pursley AA, Grebe TA, Freedenberg D, Martin RA, Hsich GE, Khera JR, Friedman NR, Zoghbi HY, Eng CM, Lupski JR, Beaudet AL, Cheung SW, Roa BB. Increased $M E C P 2$ gene copy number as the result of genomic duplication in neurodevelopmentally delayed males. Genet Med, 2006, 8: 784-792

136 Carney RM, Wolpert CM, Ravan SA, Shahbazian M, Ashley-Koch A, Cuccaro ML, Vance JM, Pericak-Vance MA. Identification of $\mathrm{MeCP} 2$ mutations in a series of females with autistic disorder. Pediatr Neurol, 2003, 28: 205-211

137 Beyer KS, Blasi F, Bacchelli E, Klauck SM, Maestrini E, Poustka A; International Molecular Genetic Study of Autism Consortium (IMGSAC). Mutation analysis of the coding sequence of the MECP2 gene in infantile autism. Hum Genet, 2002, 111: 305-309

138 Lam CW, Yeung WL, Ko CH, Poon PM, Tong SF, Chan KY, Lo IF, Chan LY, Hui J, Wong V, Pang CP, Lo YM, Fok TF. Spectrum of mutations in the MECP2 gene in patients with infantile autism and Rett syndrome. J Med Genet, 2000, 37: E41

139 Chapleau CA, Calfa GD, Lane MC, Albertson AJ, Larimore JL, Kudo S, Armstrong DL, Percy AK, Pozzo-Miller L. Dendritic spine pathologies in hippocampal pyramidal neurons from Rett syndrome brain and after expression of Rett-associated MECP2 mutations. Neurobiol Dis, 2009, 35: 219-233

140 Chapleau CA, Boggio EM, Calfa G, Percy AK, Giustetto M, Pozzo-Miller L. Hippocampal CA1 pyramidal neurons of Mecp2 mutant mice show a dendritic spine phenotype only in the presymptomatic stage. Neural Plast, 2012, 2012: 976164

141 Smrt RD, Eaves-Egenes J, Barkho BZ, Santistevan NJ, Zhao C, Aimone JB, Gage FH, Zhao X. Mecp2 deficiency leads to delayed maturation and altered gene expression in hippocampal neurons. Neurobiol Dis, 2007, 27: 77-89

142 Belichenko PV, Wright EE, Belichenko NP, Masliah E, Li HH, Mobley WC, Francke U. Widespread changes in dendritic and axonal morphology in Mecp2-mutant mouse models of Rett syndrome: evidence for disruption of neuronal networks. J Comp Neurol, 2009, 514: $240-258$

143 Nan X, Ng HH, Johnson CA, Laherty CD, Turner BM, Eisenman RN, Bird A. Transcriptional repression by the methyl-CpG-binding protein MeCP2 involves a histone deacetylase complex. Nature, 1998, 393: $386-389$

144 Jones PL, Veenstra GJ, Wade PA, Vermaak D, Kass SU, Landsberger N, Strouboulis J, Wolffe AP. Methylated DNA and $\mathrm{MeCP} 2$ recruit histone deacetylase to repress transcription. Nat Genet, 1998, 19: 187-191

145 Chahrour M, Jung SY, Shaw C, Zhou X, Wong ST, Qin J, Zoghbi HY. MeCP2, a key contributor to neurological disease, activates and represses transcription. Science, 2008, 320: 1224-1229

146 Tao J, Hu K, Chang Q, Wu H, Sherman NE, Martinowich K, Klose RJ, Schanen C, Jaenisch R, Wang W, Sun YE. Phosphorylation of $\mathrm{MeCP} 2$ at Serine 80 regulates its chromatin association and neurological function. Proc Natl Acad Sci USA, 2009, 106: $4882-4887$ 
147 Chao HT, Zoghbi HY. The yin and yang of MeCP2 phosphorylation. Proc Natl Acad Sci USA, 2009, 106: 4577-4578

148 Moretti P, Bouwknecht JA, Teague R, Paylor R, Zoghbi HY. Abnormalities of social interactions and home-cage behavior in a mouse model of Rett syndrome. Hum Mol Genet, 2005, 14: 205-220

149 Fyffe SL, Neul JL, Samaco RC, Chao HT, Ben-Shachar S, Moretti P, McGill BE, Goulding EH, Sullivan E, Tecott LH, Zoghbi HY. Deletion of $\mathrm{MeCP} 2$ in Sim1-expressing neurons reveals a critical role for MeCP2 in feeding behavior, aggression, and the response to stress. Neuron, 2008, 59: 947-958

150 Liao W, Gandal MJ, Ehrlichman RS, Siegel SJ, Carlson GC. $\mathrm{MeCP} 2+/-$ mouse model of RTT reproduces auditory phenotypes associated with Rett syndrome and replicate select EEG endophenotypes of autism spectrum disorder. Neurobiol Dis, 2012, 46: 88-92

151 Lonetti G, Angelucci A, Morando L, Boggio EM, Giustetto M, Pizzorusso T. Early environmental enrichment moderates the behavioral and synaptic phenotype of $\mathrm{MeCP} 2$ null mice. Biol Psychiatry, 2010, 67: 657-665

152 Nag N, Moriuchi JM, Peitzman CG, Ward BC, Kolodny NH, Berger-Sweeney JE. Environmental enrichment alters locomotor behaviour and ventricular volume in $M e c p 2^{I l o x}$ mice. Behav Brain Res, 2009, 196: 44-48

153 Kondo M, Gray LJ, Pelka GJ, Christodoulou J, Tam PP, Hannan AJ. Environmental enrichment ameliorates a motor coordination deficit in a mouse model of Rett syndrome-Mecp2 gene dosage effects and BDNF expression. Eur J Neurosci, 2008, 27: 3342-3350

154 Buxbaum JD, Silverman JM, Smith CJ, Greenberg DA, Kilifarski M, Reichert J, Cook EH Jr, Fang Y, Song CY, Vitale R. Association between a GABRB3 polymorphism and autism. Mol Psychiatry, 2002, 7: 311-316

155 Kim SA, Kim JH, Park M, Cho IH, Yoo HJ. Association of GABRB3 polymorphisms with autism spectrum disorders in Korean trios. Neuropsychobiology, 2006, 54: 160-165

156 Menold MM, Shao Y, Wolpert CM, Donnelly SL, Raiford KL, Martin ER, Ravan SA, Abramson RK, Wright HH, Delong GR, Cuccaro ML, Pericak-Vance MA, Gilbert JR. Association analysis of chromosome $15 \mathrm{GABA}_{\mathrm{A}}$ receptor subunit genes in autistic disorder. J Neurogenet, 2001, 15: 245-259

157 Solis-Anez E, Delgado-Luengo W, Borjas-Fuentes L, Zabala W, Arráiz N, Pineda L, Portillo MG, González-Ferrer S, Chacín JA, Peña J, Montiel C, Morales A, Rojas de Atencio A, Cañizales J, González R, Miranda LE, Abreu N, Delgado J. Molecular analysis of the GABRB3 gene in autistic patients: an exploratory study. Invest Clin, 2007, 48: 225-242

158 Yoo HK, Chung S, Hong JP, Kim BN, Cho SC. Microsatellite marker in gamma-aminobutyric acid-a receptor beta 3 subunit gene and autism spectrum disorders in Korean trios. Yonsei Med J, 2009, 50: 304-306

159 Delahanty RJ, Kang JQ, Brune CW, Kistner EO, Courchesne E, Cox NJ, Cook EH Jr, Macdonald RL, Sutcliffe JS. Maternal transmission of a rare GABRB3 signal peptide variant is associated with autism. Mol Psychiatry, 2011, 16: 86-96

160 Hogart A, Nagarajan RP, Patzel KA, Yasui DH, Lasalle JM. $15 \mathrm{q} 11-13 \mathrm{GABA}_{\mathrm{A}}$ receptor genes are normally biallelically expressed in brain yet are subject to epigenetic dysregulation in autismspectrum disorders. Hum Mol Genet, 2007, 16: 691-703

161 Homanics GE, DeLorey TM, Firestone LL, Quinlan JJ, Handforth A, Harrison NL, Krasowski MD, Rick CE, Korpi ER, Mäkelä R, Brilliant MH, Hagiwara N, Ferguson C, Snyder K, Olsen RW. Mice devoid of $\gamma$-aminobutyrate type A receptor $\beta 3$ subunit have epilepsy, cleft palate, and hypersensitive behavior. Proc Natl Acad Sci USA, 1997, 94: 4143-4148

162 DeLorey TM, Handforth A, Anagnostaras SG, Homanics GE, Minassian BA, Asatourian A, Fanselow MS, Delgado-Escueta A, Ellison GD, Olsen RW. Mice lacking the $\beta 3$ subunit of the $\mathrm{GABA}_{\mathrm{A}}$ receptor have the epilepsy phenotype and many of the behavioral characteristics of Angelman syndrome. J Neurosci, 1998, 18:
$8505-8514$

163 DeLorey TM, Sahbaie P, Hashemi E, Homanics GE, Clark JD. Gabrb3 gene deficient mice exhibit impaired social and exploratory behaviors, deficits in non-selective attention and hypoplasia of cerebellar vermal lobules: a potential model of autism spectrum disorder. Behav Brain Res, 2008, 187: 207-220

164 Ferguson C, Hardy SL, Werner DF, Hileman SM, Delorey TM, Homanics GE. New insight into the role of the $\beta 3$ subunit of the $\mathrm{GABA}_{\mathrm{A}}-\mathrm{R}$ in development, behavior, body weight regulation, and anesthesia revealed by conditional gene knockout. BMC Neurosci, 2007, 8: 85

165 Collins AL, Ma D, Whitehead PL, Martin ER, Wright HH, Abramson RK, Hussman JP, Haines JL, Cuccaro ML, Gilbert JR, Pericak-Vance MA. Investigation of autism and GABA receptor subunit genes in multiple ethnic groups. Neurogenetics, 2006, 7: 167-174

166 Ma DQ, Whitehead PL, Menold MM, Martin ER, Ashley-Koch AE, Mei H, Ritchie MD, Delong GR, Abramson RK, Wright HH, Cuccaro ML, Hussman JP, Gilbert JR, Pericak-Vance MA. Identification of significant association and gene-gene interaction of GABA receptor subunit genes in autism. Am J Hum Genet, 2005, 77: 377-388

167 Dhossche D, Applegate H, Abraham A, Maertens P, Bland L, Bencsath A, Martinez J. Elevated plasma gamma-aminobutyric acid (GABA) levels in autistic youngsters: stimulus for a GABA hypothesis of autism. Med Sci Monit, 2002, 8: PR1-PR6

168 Rolf LH, Haarmann FY, Grotemeyer KH, Kehrer H. Serotonin and amino acid content in platelets of autistic children. Acta Psychiatr Scand, 1993, 87: 312-316

169 Blatt GJ, Fitzgerald CM, Guptill JT, Booker AB, Kemper TL, Bauman ML. Density and distribution of hippocampal neurotransmitter receptors in autism: an autoradiographic study. J Autism Dev Disord, 2001, 31: 537-543

170 Fatemi SH, Reutiman TJ, Folsom TD, Rooney RJ, Patel DH, Thuras PD. mRNA and protein levels for $\mathrm{GABA}_{\mathrm{A}} \alpha 4, \alpha 5, \beta 1$ and $\mathrm{GABA}_{\mathrm{B}}$ $\mathrm{R} 1$ receptors are altered in brains from subjects with autism. J Autism Dev Disord, 2010, 40: 743-750

171 Fatemi SH, Reutiman TJ, Folsom TD, Thuras PD. GABA $A_{A}$ receptor downregulation in brains of subjects with autism. J Autism Dev Disord, 2009, 39: 223-230

172 Oblak AL, Gibbs TT, Blatt GJ. Reduced $\mathrm{GABA}_{\mathrm{A}}$ receptors and benzodiazepine binding sites in the posterior cingulate cortex and fusiform gyrus in autism. Brain Res, 2011, 1380: 218-228

173 Oblak A, Gibbs TT, Blatt GJ. Decreased $\mathrm{GABA}_{\mathrm{A}}$ receptors and benzodiazepine binding sites in the anterior cingulate cortex in autism. Autism Res, 2009, 2: 205-219

174 Ozonoff S, Iosif AM, Baguio F, Cook IC, Hill MM, Hutman T, Rogers SJ, Rozga A, Sangha S, Sigman M, Steinfeld MB, Young GS. A prospective study of the emergence of early behavioral signs of autism. J Am Acad Child Adolesc Psychiatry, 2010, 49: 256-266.e1e2

175 Volkmar FR. Childhood disintegrative disorder: issues for DSM-IV. J Autism Dev Disord, 1992, 22: 625-642

176 Kern JK, Geier DA, Sykes LK, Geier MR. Evidence of neurodegeneration in autism spectrum disorder. Transl Neurodegener, 2013, 2: 17

177 Courchesne E, Pierce K, Schumann CM, Redcay E, Buckwalter JA, Kennedy DP, Morgan J. Mapping early brain development in autism. Neuron, 2007, 56: 399-413

178 Bailey A, Luthert P, Dean A, Harding B, Janota I, Montgomery M, Rutter M, Lantos P. A clinicopathological study of autism. Brain, 1998, 121: 889-905

179 Vargas DL, Nascimbene C, Krishnan C, Zimmerman AW, Pardo CA. Neuroglial activation and neuroinflammation in the brain of patients with autism. Ann Neurol, 2005, 57: 67-81

180 Whitney ER, Kemper TL, Bauman ML, Rosene DL, Blatt GJ. Cerebellar Purkinje cells are reduced in a subpopulation of autistic brains: a stereological experiment using calbindin-D28K. Cerebellum, 2008, 7: 406-416 
181 Andersen JK. Oxidative stress in neurodegeneration: cause or consequence? Nat Med, 2004, 10 Suppl: S18-S25

182 Sajdel-Sulkowska EM, Xu M, Koibuchi N. Increase in cerebellar neurotrophin-3 and oxidative stress markers in autism. Cerebellum, 2009, 8: 366-372

183 Sajdel-Sulkowska EM, Xu M, McGinnis W, Koibuchi N. Brain region-specific changes in oxidative stress and neurotrophin levels in autism spectrum disorders (ASD). Cerebellum, 2011, 10: 43-48

184 Chauhan A, Gu F, Essa MM, Wegiel J, Kaur K, Brown WT, Chauhan V. Brain region-specific deficit in mitochondrial electron transport chain complexes in children with autism. J Neurochem, 2011, 117: 209-220

185 Frustaci A, Neri M, Cesario A, Adams JB, Domenici E, Dalla Bernardina B, Bonassi S. Oxidative stress-related biomarkers in autism: systematic review and meta-analyses. Free Radic Biol Med, 2012, 52: 2128-2141

186 Liu X, Solehdin F, Cohen IL, Gonzalez MG, Jenkins EC, Lewis ME, Holden JJ. Population- and family-based studies associate the MTHFR gene with idiopathic autism in simplex families. J Autism Dev Disord, 2011, 41: 938-944

187 Pasca SP, Dronca E, Kaucsar T, Craciun EC, Endreffy E, Ferencz BK, Iftene F, Benga I, Cornean R, Banerjee R, Dronca M. One carbon metabolism disturbances and the C677T MTHFR gene polymorphism in children with autism spectrum disorders. J Cell Mol Med, 2009, 13: 4229-4238

188 James SJ, Melnyk S, Jernigan S, Cleves MA, Halsted CH, Wong DH, Cutler P, Bock K, Boris M, Bradstreet JJ, Baker SM, Gaylor DW. Metabolic endophenotype and related genotypes are associated with oxidative stress in children with autism. Am J Med Genet B Neuropsychiatr Genet, 2006, 141B: 947-956

189 Mohammad NS, Jain JM, Chintakindi KP, Singh RP, Naik U, Akella RR. Aberrations in folate metabolic pathway and altered susceptibility to autism. Psychiatr Genet, 2009, 19: 171-176

190 Buyske S, Williams TA, Mars AE, Stenroos ES, Ming SX, Wang R, Sreenath M, Factura MF, Reddy C, Lambert GH, Johnson WG. Analysis of case-parent trios at a locus with a deletion allele: association of GSTM1 with autism. BMC Genet, 2006, 7: 8

191 Leoni V. The effect of apolipoprotein E (ApoE) genotype on biomarkers of amyloidogenesis, tau pathology and neurodegeneration in Alzheimer's disease. Clin Chem Lab Med, 2011, 49: 375-383

192 Obulesu M, Somashekhar R, Venu R. Genetics of Alzheimer's disease: an insight into presenilins and apolipoprotein $\mathrm{E}$ instigated neurodegeneration. Int J Neurosci, 2011, 121: 229-236

193 Liu CC, Kanekiyo T, Xu H, Bu G. Apolipoprotein E and Alzheimer disease: risk, mechanisms and therapy. Nat Rev Neurol, 2013, 9: 106-118

194 Corder EH, Lannfelt L, Bogdanovic N, Fratiglioni L, Mori H. The role of APOE polymorphisms in late-onset dementias. Cell Mol Life Sci, 1998, 54: 928-934

195 Giunco CT, de Oliveira AB, Carvalho-Salles AB, Souza DS, Silva AE, da Rocha SS, Fett-Conte AC. Association between APOE polymorphisms and predisposition for autism. Psychiatr Genet, 2009, 19: 338

196 Persico AM, D’Agruma L, Zelante L, Militerni R, Bravaccio C, Schneider C, Melmed R, Trillo S, Montecchi F, Elia M, Palermo M, Rabinowitz D, Pascucci T, Puglisi-Allegra S, Reichelt KL, Muscarella L, Guarnieri V, Melgari JM, Conciatori M, Keller F. Enhanced APOE2 transmission rates in families with autistic probands. Psychiatr Genet, 2004, 14: 73-82

197 Bothwell M, Giniger E. Alzheimer's disease: neurodevelopment converges with neurodegeneration. Cell, 2000, 102: 271-273

198 Knuesel I. Reelin-mediated signaling in neuropsychiatric and neurodegenerative diseases. Prog Neurobiol, 2010, 91: 257-274

199 Fatemi SH. Reelin glycoprotein: structure, biology and roles in health and disease. Mol Psychiatry, 2005, 10: 251-257

200 Kelemenova S, Schmidtova E, Ficek A, Celec P, Kubranska A, Ostatnikova D. Polymorphisms of candidate genes in Slovak autistic patients. Psychiatr Genet, 2010, 20: 137-139
201 Persico AM, D’Agruma L, Maiorano N, Totaro A, Militerni R, Bravaccio C, Wassink TH, Schneider C, Melmed R, Trillo S, Montecchi F, Palermo M, Pascucci T, Puglisi-Allegra S, Reichelt KL, Conciatori M, Marino R, Quattrocchi CC, Baldi A, Zelante L, Gasparini P, Keller F; Collaborative Linkage Study of Autism. Reelin gene alleles and haplotypes as a factor predisposing to autistic disorder. Mol Psychiatry, 2001, 6: 150-159

202 Ashley-Koch A, Wolpert CM, Menold MM, Zaeem L, Basu S, Donnelly SL, Ravan SA, Powell CM, Qumsiyeh MB, Aylsworth AS, Vance JM, Gilbert JR, Wright HH, Abramson RK, DeLong GR, Cuccaro ML, Pericak-Vance MA. Genetic studies of autistic disorder and chromosome 7. Genomics, 1999, 61: 227-236

203 International Molecular Genetic Study Of Autism Consortium. A full genome screen for autism with evidence for linkage to a region on chromosome 7q. Hum Mol Genet, 1998, 7: 571-578

204 Del Rio JA, Heimrich B, Borrell V, Förster E, Drakew A, Alcántara S, Nakajima K, Miyata T, Ogawa M, Mikoshiba K, Derer P, Frotscher M, Soriano E. A role for Cajal-Retzius cells and reelin in the development of hippocampal connections. Nature, 1997, 385: $70-74$

205 Goffinet AM. Events governing organization of postmigratory neurons: studies on brain development in normal and reeler mice. Brain Res, 1984, 319: 261-296

206 Walsh DM, Minogue AM, Sala Frigerio C, Fadeeva JV, Wasco W, Selkoe DJ. The APP family of proteins: similarities and differences. Biochem Soc Trans, 2007, 35: 416-420

207 Zhang YW, Thompson R, Zhang H, Xu H. APP processing in Alzheimer's disease. Mol Brain, 2011, 4: 3

208 Rohan de Silva HA, Jen A, Wickenden C, Jen LS, Wilkinson SL, Patel AJ. Cell-specific expression of beta-amyloid precursor protein isoform mRNAs and proteins in neurons and astrocytes. Brain Res Mol Brain Res, 1997, 47: 147-156

209 Zheng H, Koo EH. The amyloid precursor protein: beyond amyloid. Mol Neurodegener, 2006, 1: 5

210 Selkoe DJ. Biochemistry and molecular biology of amyloid $\beta$-protein and the mechanism of Alzheimer's disease. Handb Clin Neurol, 2008, 89: 245-260

211 Kamenetz F, Tomita T, Hsieh H, Seabrook G, Borchelt D, Iwatsubo T, Sisodia S, Malinow R. APP processing and synaptic function. Neuron, 2003, 37: 925-937

212 Frackowiak J, Mazur-Kolecka B, Schanen NC, Brown WT, Wegiel J. The link between intraneuronal N-truncated amyloid- $\beta$ peptide and oxidatively modified lipids in idiopathic autism and $\operatorname{dup}(15 \mathrm{q} 11.2-$ q13)/autism. Acta Neuropathol Commun, 2013, 1: 61

213 Wegiel J, Frackowiak J, Mazur-Kolecka B, Schanen NC, Cook EH Jr, Sigman M, Brown WT, Kuchna I, Wegiel J, Nowicki K, Imaki H, Ma SY, Chauhan A, Chauhan V, Miller DL, Mehta PD, Flory M, Cohen IL, London E, Reisberg B, de Leon MJ, Wisniewski T. Abnormal intracellular accumulation and extracellular $A \beta$ deposition in idiopathic and Dup15q11.2-q13 autism spectrum disorders. PLoS One, 2012, 7: e35414

214 Sokol DK, Chen D, Farlow MR, Dunn DW, Maloney B, Zimmer JA, Lahiri DK. High levels of Alzheimer beta-amyloid precursor protein (APP) in children with severely autistic behavior and aggression. J Child Neurol, 2006, 21: 444-449

215 Devlin B, Scherer SW. Genetic architecture in autism spectrum disorder. Curr Opin Genet Dev, 2012, 22: 229-237

216 Jamain S, Betancur C, Giros B, Leboyer M, Bourgeron T. Genetics of autism: from genome scans to candidate genes. Med Sci (Paris), 2003, 19: $1081-1090$

217 Klei L, Sanders SJ, Murtha MT, Hus V, Lowe JK, Willsey AJ, Moreno-De-Luca D, Yu TW, Fombonne E, Geschwind D, Grice DE, Ledbetter DH, Lord C, Mane SM, Martin CL, Martin DM, Morrow EM, Walsh CA, Melhem NM, Chaste P, Sutcliffe JS, State MW, Cook EH Jr, Roeder K, Devlin B. Common genetic variants, acting additively, are a major source of risk for autism. Mol Autism, 2012, 3: 9 
218 Willsey AJ, Sanders SJ, Li M, Dong S, Tebbenkamp AT, Muhle RA, Reilly SK, Lin L, Fertuzinhos S, Miller JA, Murtha MT, Bichsel C, Niu W, Cotney J, Ercan-Sencicek AG, Gockley J, Gupta AR, Han W, He X, Hoffman EJ, Klei L, Lei J, Liu W, Liu L, Lu C, Xu X, Zhu Y, Mane SM, Lein ES, Wei L, Noonan JP, Roeder K, Devlin B, Sestan N, State MW. Coexpression networks implicate human midfetal deep cortical projection neurons in the pathogenesis of autism. Cell, 2013, 155: 997-1007

219 Parikshak NN, Luo R, Zhang A, Won H, Lowe JK, Chandran V, Horvath S, Geschwind DH. Integrative functional genomic analyses implicate specific molecular pathways and circuits in autism. Cell, 2013, 155: 1008-1021

Open Access This article is distributed under the terms of the Creative Commons Attribution License which permits any use, distribution, and reproduction in any medium, provided the original author(s) and source are credited. 